\title{
Estimating the long-term economic impacts of Spanish universities on the national economy ${ }^{*}$
}

\author{
José M. Pastor ${ }^{1,2}$, Carlos Peraita ${ }^{2}$, Francisco Pérez ${ }^{1,2}$ \\ ${ }^{1}$ Instituto Valenciano de Investigaciones Económicas (IVIE), Carrer de la Guàrdia Civil, 22, 46020 Valencia, Spain \\ (e-mail: Jose.M.Pastor@uv.es, francisco.perez@ivie.es) \\ 2 Facultad de Economía, Universitat de València, Avenida de los Naranjos s/n, Valencia, Valencia 46022, Spain \\ (e-mail: carlos.peraita@uv.es)
}

Received: 5 February 2014 / Accepted: 3 December 2014

\begin{abstract}
In contrast to previous studies on the economic impact of universities that focus on the demand side, this study centres on universities' effects on the supply side of the economy. Through a case study of the Spanish University System, this paper proposes a methodology based on counterfactual scenarios and growth accounting to estimate the long-term impacts of universities on their regional economies. Our study evaluates the stylized impacts of universities' activities on human capital, salaries and occupation of the working age population, on generation of technological capital and, finally, on the GDP growth of the Spanish economy in the period 1989-2010.
\end{abstract}

\section{JEL classification: I23, I25}

Key words: Universities, long-term economic impacts, human capital, technological capital, economic growth

\section{Introduction}

Today there is no question that the activities of universities have economic and social impacts on their surrounding environments. In recent years, neither governments nor the universities themselves have been particularly aware of their contribution to the regions in which they are located. This situation is now changing, as it is clear that universities make a decisive contribution in stimulating their local and regional economies (OECD 2007). Recognition of this circumstance has prompted numerous studies (Drucker and Golstein 2007) to analyse the economic and social contributions of universities in several OECD countries.

One such study is the literature review conducted by Arbo and Benneworth (2007). Their report offers an overview of the development of higher education institutions in the regional

* The authors would like to thank the Editor and three anonymous reviewers for their valuable comments and suggestions to improve the quality of the paper. The authors are grateful for funding from Research Project ECO201123248 (Ministry of the Economy and Competitiveness). 
context from a selection of studies of European and North American universities. Universities have a key role to play in knowledge creation and its translation into innovative products and public and private services. The European Commission published a guide (Goddard and Kempton 2011) to help improve the contribution of universities to regional development, with a view to strengthening economic, social and territorial cohesion in a sustainable way.

Most of these studies focus on quantifying the short-term impacts of university activity on employment and demand in local firms through the universities' own spending or the expenditure they induce in other agents. However, these studies do not take into account some of the universities' long-term socio-economic contributions, such as the increase in society's endowments of human and technological resources, which as well as generating economic growth, also facilitate the transformation of productive structures or other external market benefits (McMahon 2009).

Universities increase the human capital embodied in their graduates and, therefore, the human capital available in the economy, which has a crucial economic impact. With the growth of the university-educated population comes an increase in the number of employed persons, as university graduates have higher rates of activity and employment and lower rates of unemployment than the average for the active population. University graduates are also more productive workers due to their superior skills, and earn higher salaries than people with lower educational levels. These impacts on employment, productivity and salaries are more important than impacts on the demand side because their effects last much longer. Equally, universities' R\&D activities generate scientific and technological knowledge which is used by the productive system and also has an impact on technological capital. In sum, universities have positive effects on the accumulation of both human and technological capital and therefore generate positive impacts on income and the growth of the economy that raise levels of economic and social wellbeing.

Although the literature recognizes the positive effects of universities' activities on economic development, to date, studies have not provided homogeneous indicators to quantify these long-term economic effects on regional economies. The main contribution of this paper lies in its proposal of a new methodology to estimate universities' long-term economic impacts. We propose the conditional counterfactual question: if the Spanish universities had not existed, then what would have been the effect on the national economy? The disadvantage of dealing explicitly with this counterfactual case may be that it is unrealistic, but it has the advantage of allowing us to establish econometric scenarios formulated as sets of regression equations.

This paper proposes a methodology to estimate the long-term impacts of universities on their regional economies and quantifies these impacts for the case of the Spanish university system (SUS), which consists of 81 universities attended by around 1.6 million students. We use this methodology to answer the following specific questions: How much human capital have Spanish universities generated? What is the value of the human capital generated? Do the Spanish universities make a significant contribution to generating technological capital? What is their impact on activity and unemployment rates? What is their contribution to Spain's long-term economic growth?

The paper is organized as follows. Section 2 briefly outlines the literature on economic impacts of university activity. Section 3 describes the models used to estimate the long-term economic impacts of the SUS, the results of which are presented in Section 4. Finally, Section 5 concludes.

\section{Contributions of universities to the economy: The literature}

The first studies on the economic impact of universities began to appear in the 1980s in the United States, Canada and, less frequently, Europe. These studies attempted to quantify the 
impacts that universities' current spending on staff and infrastructures has on regional economic development. Later studies (Drucker and Goldstein 2007) analyse the types of impacts that influence the economy, including knowledge creation, creation of human capital, transfer of existing technical knowledge, technological innovation, capital investment, leadership and creation of infrastructures for the production of knowledge.

Leslie and Slaughter (1992) survey around 60 reports up to 1992. Siegfried et al. (2007) review the results of another 138 impact studies published since 1992. Their paper describes the methodological approaches and pitfalls common to studies of the economic impact of colleges and universities. The short-term results of these positive impacts of university expenditure on the economy are so robust and consistent that they have stimulated interest among universities and regional governments to have reliable estimations of the economic impacts of universities on the environments they influence. As an illustration, Carroll and Smith (2006, p. 1) state that the most widely reported finding in the media is that 'for every dollar Bowling Green State University received in state support it returned a conservative estimate of $\$ 8$ in economic activity to Ohio's economy'.

Other studies present universities as central actors in the knowledge-based economy as promoters of technological change and innovation. Simha (2005) reviews the implications of this large concentration of research activity on the Boston region, labour force, pre and postuniversity educational structures, political leadership, funding sources and social and environmental quality. The studies of Bramwell and Wolfe (2008) and Power and Malmberg (2008) illustrate the way in which universities have contributed to economic growth and innovation in their local and regional economies.

The impact of research universities on regional development has been tested by many studies, showing that university impacts are statistically significant. Thus, according to Lendel (2010), the presence of research universities has a positive effect on their regional economies that goes beyond cyclical economic changes and the effect differs depending on the scale of university R\&D expenditures. Lane and Johnstone (2012) examine the relationship between higher education and economic development and, again, show that through their roles in education, innovation, knowledge transfer and community engagement, universities are working towards economic growth and prosperity and that they play a central role in national, state, and local economies. In summary, all these studies find evidence that employment growth rates and earnings are higher in areas with good universities.

Empirical evidence identifies various channels through which universities contribute significantly to the long-term growth and development of their societies. Thus, the literature finds a positive relationship between greater education of the individual and greater activity, occupation and income (OECD 2009). Similarly, a positive effect of education on economic growth has also been verified (Glaeser and Saiz 2003; Moretti 2004). Additionally, the virtuous circle of university education (Basant and Mukhopadhyay 2009) implies that economic growth can be attributed in large measure to scientific and technological improvements associated with increases in the productivity of labour, technological capital and other factors such as knowledge and innovation.

Goldstein and Renault (2004) find that universities potentially contribute to regional economic development in a number of ways like research, creation of human capital, technology development and transfer, etc. Varga (2009) focuses on the transfer of new and economically useful knowledge from universities to the regional economy, and compiles papers on three issues dominating current research, namely, the geography of academic knowledge transfers; the mechanisms of these transfers in terms of academic entrepreneurship and graduate mobility; and policy experience in university-based regional economic development. Anselin et al. (1997) provide empirical evidence of the degree of spatial diffusion between university research and high technology innovations in the United States. Feldman and Desrochers (2003) examine the 
evolution of university practices and policies towards technology transfer and they aim to extend the debate on the role of the university in the regional innovation system.

The study by Sudmant (2009) incorporates concepts adapted from the literature on the economy of education, knowledge and innovations and economic growth. The study's central idea is that the economic impacts of universities are different from those attributable to other organizations because as well as the 'static impact' (the traditional one) on the economy, universities also have a 'dynamic impact' that increases the productive capacity of the economy. The Forum for the Future of Higher Education, coordinated by Porter (2007) at Harvard University, highlights this relationship between the economic prosperity of the regions and the health of their university institutions.

Most studies on the economic impact of a university ${ }^{1}$ use different methodologies to estimate the direct and indirect effects of university spending, investment and employment on their regions. Garrido-Yserte and Gallo-Rivera (2010) classified them into two groups according to the required information: direct estimation methods and indirect estimation methods. The first group includes the American Council of Education method where impacts are estimated from detailed information coming directly from surveys of the principal agents. This method, developed by Caffrey and Isaacs (1971), has been applied in over a quarter of North American universities (e.g., Leslie and Lewis 2001) and adapted versions of it are still used. It consists of identifying the various economic impacts that a university generates in its location and proposes simple models for each of them. These models allow us to estimate universities' economic impact.

In the second group are the input-output method and the Ryan shortcut model, which use secondary information to indirectly estimate the impacts on the local economy. First, the input-output analysis estimates the effects of the spending made by the university and agents related to the university (students, visitors, congress attendees, etc.) on the local economy. Second, the Ryan shortcut method (Ryan and Malgieri 1992) reduces the complexity of the sub-models developed by Caffrey and Isaacs and simplifies the data collection process by using existing information from local, regional and national sources instead of surveying university students and employees. ${ }^{2}$ Of all the approaches noted, the advantages offered by input-output analysis make it the most widely used. These studies are known as short-term demand-side economic impact studies, and quantify the effect of university activity expenditure on income and employment in the economy.

In contrast to other European countries, such as the United Kingdom where economic impact has been studied for many years, ${ }^{3}$ there are few studies on the economic impact of universities' activity in Spain, and those carried out before 2008 quantify only the short-term demand-side economic effects of universities (Garrido-Yserte and Gallo-Rivera 2010). More recently, the paper by Pastor et al. (2013) focuses on the impact of the demand-side effects of Valencian public universities by designing a methodology based on Monte Carlo simulations so as to introduce stochastic elements.

The study for the University of the Basque Country (Pastor and Pérez 2008) is the first to analyse the impacts on the economy both on the demand side and the long-term effects on the supply side. This line of research has continued with Pastor and Pérez (2009) for the public

1 These studies use an IMPLAN (IMpact analysis for PLANning) type input-output model to estimate the effects of the university on the economy of the state (with SAM, social accounting matrices, type multipliers). The methodology used was designed by the American Council of Education (ACE) which in 1968 drew up a detailed guide to measuring the economic benefits of colleges and universities to their local communities. The first reports were based on the pioneering study by Caffrey and Isaacs (1971).

2 Other models are the Keynesian local multiplier model (Bleaney et al. 1992; Canterbury City Council 2001) and computable general equilibrium models (Giesecke and Madden 2005).

3 The work of Kelly et al. (2009) updates earlier studies on the impact of the higher education sector on the UK economy published since 1997. 
system of universities in the Valencia region and, more recently, with the study by Pastor and Peraita (2012) which uses the methodology of the earlier studies to analyse the socio-economic contribution of Spanish universities to the national economy. The approach of these studies is reflected in this paper and consists of estimating the long-term economic impacts of the Spanish university system on the national economy, based on existing empirical evidence of the diverse ways universities contribute to economic and social development.

\section{Methodology for estimating the long-term economic impacts of university activity}

This section presents methodological proposals for measuring the long-term impacts of universities on the supply of resources in the economy. They are applied to the case of the Spanish university system's (SUS) impacts on the Spanish economy. The SUS's supply-side impacts are estimated using a counterfactual scenario, that is, a hypothetical situation in which the SUS does not exist.

The use of counterfactual scenarios is a widespread technique in the social sciences where real experiments cannot be performed. It should be noted that this approach involves assuming that all other factors remain constant and that no other type of dynamic adjustment exists. ${ }^{4}$ The recommended procedure when using counterfactual scenarios (Fearon 1996) is to restrict the study to analysing a single aspect and a single explanatory variable and not to add or create more cases. The approach followed in the present paper is, therefore, to analyse the contribution of the SUS by comparing the real situation with another hypothetical situation in which the SUS does not exist, and maintaining everything else constant. Although this may appear somewhat unrealistic, it is much more risky to establish additional hypotheses, about which we know nothing, on how other universities (foreign or private) might have behaved, or on student mobility.

Figure 1 shows some of the impacts of SUS activity from a long-term perspective and considers the effects produced on the supply side. The figure offers a simplified version of the universities' relationships with their economies and shows two effects of the universities' supply-side contributions; first, those of SUS activity on the endowments of resources available (employment, human capital, technological capital, etc.); and second, the subsequent effects deriving from this increase in available resources (economic growth, improvement in income, tax revenue, etc.) that are long-lasting, and hence are of greater potential importance for the Spanish economy.

\subsection{Human capital}

The generation of human capital by the SUS through the training of university graduates is the most important, and certainly the most visible, direct quantitative contribution to the Spanish economy in terms of economic value of the output and also of their contribution to economic growth. ${ }^{5}$ To measure human capital we use the synthetic indicator of average years of education of the population. Specifically, we compute the impact of the SUS on the increase in human capital as the difference between the average years of education of the working age population of Spain and the counterfactual average years of education, namely, those that would have been achieved had the SUS not existed, and therefore had not trained university graduates.

\footnotetext{
${ }^{4}$ This approach implies assuming that, for example, no private or foreign universities have appeared to fill the gap in the education market, and that there are no migratory patterns of students travelling abroad to study.

${ }^{5}$ See Table 2 for the value of (human capital) output and Table 6 for the contribution of labour to the GPD.
} 


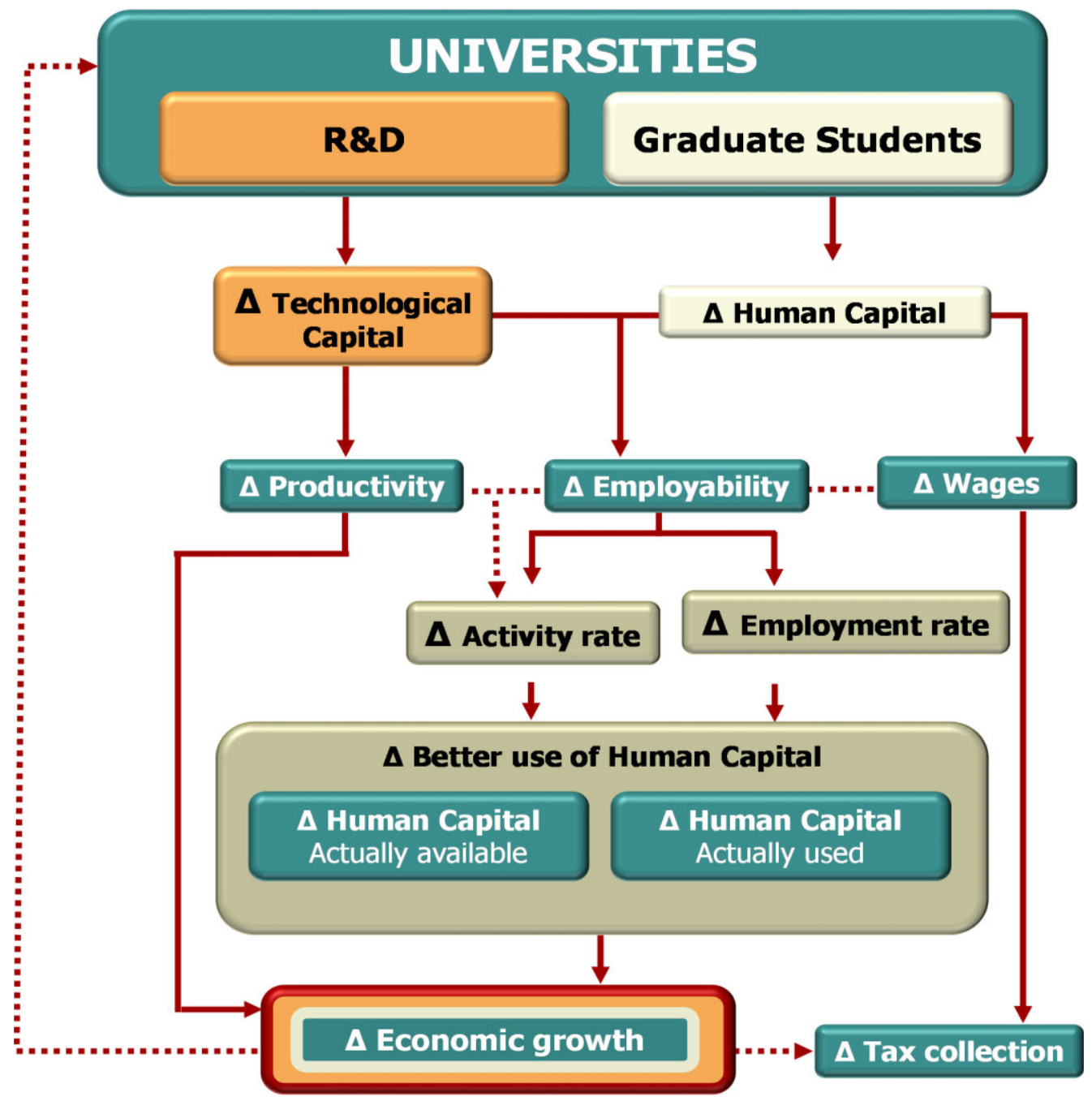

Fig. 1. The Contribution of Universities to Economic Growth Source: Own preparation.

The counterfactual years of education series (those that the population of Spain aged between 16 and 65 would have if the SUS had not trained university graduates) are calculated by considering that had the SUS not existed those leaving education would have attained the educational level prior to university (post-compulsory secondary education).

Since the SUS raises individuals' educational levels, let us suppose that the teaching activity of the SUS consists of 'transforming' individuals who enter the university with a postcompulsory secondary educational level (S) and a certain earning capacity $\left(\mathrm{w}_{\mathrm{S}}\right)$ into individuals with a university education (U) and with a higher earning capacity $\left(\mathrm{w}_{\mathrm{U}}\right)$, where $\mathrm{w}_{\mathrm{U}}>\mathrm{w}_{\mathrm{S}}$. Thus, the present value of the increase in salaries over a working lifetime deriving from the university qualification is an economic measure of the value of the human capital generated by the SUS (Serrano and Pastor 2002).

To calculate the economic value of human capital two educational levels are considered: post-compulsory secondary, and university. We will assume that the retirement age is 65 years. The economic value of human capital in each period is obtained by imputing to each university 
graduate the increase in human capital wealth that he/she obtains from graduating. In other words, this is the increase in the present value of the salaries that each graduate will receive for having completed university over a post-compulsory secondary education level. Aggregating for the whole set of graduates of the SUS in each year we obtain the economic value of the human capital generated annually by the Spanish universities. The long-term evolution of an individual's earnings is a function of the level of education he/she has reached:

$$
w_{e, t}=w_{e, t-1}(1+g),
$$

where $w$ is the individual earnings in real terms, the sub index $e$ indicates the educational level attained and $g$ is the real long-term growth rate of earnings. Therefore, the updated value of the earnings over a working lifetime will be equal to:

$$
h_{e, t}=\sum_{T=0}^{T=W L} \frac{w_{e, t+T}}{(1+r)^{T}},
$$

where $r$ is the real long-term interest rate used to adjust future income to the present, and $W L$ is the duration of each individual's working life starting from the period $t$ in which he/she graduates from university. Therefore, the investment in human capital an individual makes by going to university is the increase in his/her income over his/her working lifetime, as a consequence of going from post-compulsory secondary education $(e-1)$ to university education $(e)$ :

$$
i_{e, 0}=h_{e, 0}-h_{e-1,0}
$$

The potential economic value of the output (human capital) generated by the SUS in period $t\left(Y H_{t}\right)$ is the sum of all the individual investments made by its university graduates linked to the changes in educational level produced during period $t$ :

$$
Y H_{0}=\sum i_{e, 0} .
$$

The procedure used in Equation (4) is the one proposed by Jorgenson and Fraumeni (1992) to estimate human capital wealth from the present value of wages that individuals will obtain over their working lives and does not consider the effects on the rate of activity and occupation. Therefore, the value of Equation (4) refers to the potential value of the output of SUS. To perform these calculations the same assumptions are made about the level of education that the individual would have attained had he/she not entered university. That is to say that, just as in calculating the counterfactual years of education, we assume that the individuals who did not study at university completed post-compulsory secondary education (see subsection 4.1).

\subsection{Activity rate and employment}

Model (1) of Table 1 presents the estimation of a conventional probit model of determinants of participation in the labour market. The data are taken from the activity rate and employment. The dichotomous dependent variable is being active (1) or being inactive (0) in the labour market, and the dependent variables are listed in the table. Model (1) shows that individuals with a higher level of education, and especially university graduates, tend to have greater probability of participation in the labour market. Of course there are many other effects of higher education ${ }^{6}$

\footnotetext{
${ }^{6}$ Elhorst and Zeilstra (2007) show several reasons for why the higher educated are better off than the lower educated.
} 
Table 1. Estimation of labor activity and occupation

\begin{tabular}{|c|c|c|c|c|}
\hline & \multicolumn{2}{|c|}{ (1) Labour activity } & \multicolumn{2}{|c|}{ (2) Occupation } \\
\hline & Parameters & $\begin{array}{l}\text { Marginal effect } \\
\text { on probability }\end{array}$ & Parameters & $\begin{array}{c}\text { Marginal effect } \\
\text { on probability }\end{array}$ \\
\hline Constant & -0.049 & & -0.622 & \\
\hline Woman & $-0.466^{* *}$ & -0.174 & $-0.164 * *$ & -0.058 \\
\hline Age $25-34$ & $1.199 * *$ & 0.359 & $0.762 * *$ & 0.228 \\
\hline Age $35-44$ & $1.217 * *$ & 0.369 & $0.918 * *$ & 0.268 \\
\hline Age $45-54$ & $1.028 * *$ & 0.320 & $0.993 * *$ & 0.278 \\
\hline Age $55+$ & $-0.426^{* *}$ & -0.163 & $0.779 * *$ & 0.251 \\
\hline No education & $-0.605 * *$ & -0.237 & $-0.425 * *$ & -0.159 \\
\hline Compulsory Secondary & $0.354 * *$ & 0.129 & $0.220 * *$ & 0.075 \\
\hline Post compulsory Sec. & $0.424 * *$ & 0.151 & $0.437 * *$ & 0.142 \\
\hline HNVQ & $0.674 * *$ & 0.219 & $0.627 * *$ & 0.185 \\
\hline Diploma & $0.682 * *$ & 0.221 & $0.764 * *$ & 0.216 \\
\hline Graduate & $0.818 * *$ & 0.258 & $0.789 * *$ & 0.224 \\
\hline Spanish & $-0.178 * *$ & -0.065 & $0.311 * *$ & 0.115 \\
\hline Number of observations & \multicolumn{2}{|c|}{144,451} & \multicolumn{2}{|c|}{144,451} \\
\hline Log-Likelihood & \multicolumn{2}{|c|}{$-16,533,243$} & \multicolumn{2}{|c|}{$-28,300,000$} \\
\hline
\end{tabular}

Source: INE and own preparation.

Notes: ** significant at $1 \%$. HNVQ is higher grade of vocational training. Observations are from entire working age population.

but they fall beyond the scope of the present study. Indeed, higher education has a positive effect on labour supply, not only because it increases the number of individuals in the labour market but also because these individuals want to allocate more hours to paid work. Therefore, the contribution of universities to increasing labour force participation by way of an increase in the university educated population would be greater than estimated.

Thus, the marginal effects on probability show that education has a positive and statistically significant effect on the probability of being active when other characteristics are constant. Results show that the greatest effect on the probability of being active is associated with long-cycle university studies (compared to primary studies). For example, when an individual with primary studies completes post-compulsory secondary studies, the results show that the probability of his or her being active in the labour market increases by 15.1 per cent, whereas an individual with long-cycle university studies has 25.8 per cent more probability of being active in the labour market (representing more than 10.5 percentage points in the activity rate).

The first step in the procedure is to compute the effect on the activity rate of holding a university qualification. The next step is to measure how much the SUS has contributed to the increase in the activity rate by training university graduates. We will consider the information on the number of university graduates from the Spanish universities and compute the counterfactual activity rate which eliminates the contribution of the SUS. ${ }^{7}$ To calculate the contribution of the SUS we construct a counterfactual scenario in which we eliminate the positive effect on the activity rate of having a university qualification. The comparison of this counterfactual activity rate with the real activity rate (calculated on the entire working age population) provides a measure of the contribution of the SUS. In the construction of the counterfactual rate the effect

\footnotetext{
7 This approach implies assuming that the effects of human capital are linear. However, when the level of human capital is higher in an economy, two opposite effects occur. On the one hand, the positive effects of human capital on salaries, participation and employment rates are relatively low. On the other hand, there is evidence (Acemoglu and Autor 2011; Autor and Price 2013; and Autor et al. 2003) to show that higher levels of human capital in economies cause intensive technological progress in human capital that favours increased productivity. These two effects are difficult to quantify, and this circumstance should be borne in mind when interpreting the results.
} 
of the educational level on the activity rate is isolated from the individuals' other characteristics which also influence their probability of participating in the labour market.

Current Spanish labour market data also shows another conventional relationship: the higher an individual's level of education, the lower his/her likelihood of unemployment. For instance, in Spain in 2011 the unemployment rates of university graduates were about 80 per cent lower than those of the illiterate population and almost 65 per cent lower than those with no education or with only primary education. Model (2) in Table 1 uses the same data as model (1) and presents a two-stage model (Heckman 1979) of the determinants of occupation in the Spanish economy. The dichotomous dependent variable is being occupied (1) or not being occupied (0), and the dependent variables are listed in the table. The results of estimating model (2) indicate that education has a positive and statistically significant effect on the probability of employment when all other personal characteristics are similar. The marginal effects on probability for an individual with primary studies show that completing post-compulsory secondary studies increases the probability of being occupied by 14.2 per cent, whereas an individual with long-cycle university studies has 22.4 per cent more probability of being occupied (representing 8 percentage points in the employment rate).

The next step is to compute the impact of the SUS on employment in the Spanish economy. This impact can be expressed as the difference between the real and the counterfactual occupied populations. This latter variable is the occupied population Spain would have if the SUS had not trained university graduates, and therefore Spanish university graduates would have the same probability of being employed as the individuals with post-compulsory education (see subsection 4.2).

\subsection{Technological capital}

The third long-term impact of university activity we measure in this paper concerns the technological capital of the economy. Universities' research and technological development $(R \& D)$ represents a substantial part (27.8 per cent) of the expenditure and income generated by the SUS, about 4 percentage points above the European Union average. The OECD (Frascati 2002) defines R\&D spending as all creative work carried out on a systematic basis, with the aim of increasing the stock of knowledge and the use of that stock to devise new applications. This definition allows us to quantify the SUS's contribution to the generation of technological capital in Spain by means of R\&D spending. Technological capital is obtained from the accumulation of payment flows to personnel, of inputs and of investments in equipment and installations necessary for carrying out $R \& D$ activities.

To estimate the series of technological capital stock generated by the SUS, following Puente and Pérez (2004) we use the inventory method according to the expression:

$$
K T_{i, t}=(1-\delta) K T_{i, t-1}+I_{i, t-\theta},
$$

where $K T_{i, t}$ is the capital stock of period $t, \delta$ is the rate of depreciation and $I$ is the rate of investment in period $t$. According to Pakes and Schankerman (1984), the effects of investment in $R \& D$ are assumed to be incorporated into the technological capital stock, and the capital stock is estimated as described below:

$$
K T_{i, t}=\frac{I_{i, t-\theta}}{g+\delta},
$$

$g$ being the rate of growth of investment in R\&D. 


\subsection{Economic growth}

This subsection presents the procedure to estimate the sources of growth of the Spanish economy and the proportion that can be attributed to the SUS. We use the growth accounting approach proposed by Solow (1957) to estimate the SUS contribution to economic growth in Spain.

We assume four productive factors and an expanded production function where production $(Y)$ in period $t$ depends on the state of technology $(A)$, the capital employed $(K)$, accumulated technological capital $(K T)$ and the labour employed measured as total years of education $(A E T=L \cdot A S)$, which is the product of the number of people employed $(L)$ and their average years of education $(A S) .{ }^{8}$ The impact of the SUS on the growth of the Spanish economy is therefore produced through the three effects noted above: the quantity effect (on L), the quality effect (on AS), and the technological capital effect (on $K T$ ). The expanded production function is:

$$
Y_{t}=A_{t} K_{t}^{\alpha} A E T_{t}^{\beta} K T_{t}^{\lambda}=A_{t} K_{t}^{\alpha}\left(L_{t} A S_{t}\right)^{\beta} K T_{t}^{\lambda},
$$

where $\alpha, \beta$ and $\lambda$ are the shares of the income of capital, labour (wages) and technological capital in the total income, respectively. Taking logarithms (variables in lower case) and first differences (d) with respect to time, Equation (7) is written:

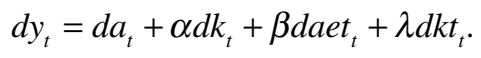

This expression allows growth of GDP $\left(d y_{t}\right)$ to be decomposed into the contribution of capital $\left(\alpha d k_{t}\right)$, the contribution of the total quantity of labour $\left(\beta d a e t_{t}\right)$, the contribution of technological capital $\left(\lambda d k t_{t}\right)$ and, finally, the contribution of total factor productivity $\left(d a_{t}\right)$.

Total labour growth $(A E T)$ is expressed as the weighted mean of the total labour growth associated with the existence of the SUS $\left(A E T^{S U S}\right)$ and the counterfactual economic growth that would be observed if the SUS did not exist $\left(A E T^{C F}\right)$ according to the following expression:

$$
\widehat{A E T}_{t}=\left[\theta \widehat{A E T}_{t}^{S U S}+(1-\theta) \widehat{A E T}_{t}^{C F}\right]
$$

where the circumflex symbol above the variables denotes rates of variation, $\theta$ is the proportion of the total years of education generated by the SUS, and $(1-\theta)$ is the proportion of the rest of the years of education in the total. Given that the total labour AET is the product of the average years of education and the number of occupied persons, Equation (9) can be written thus:

$$
\widehat{A E T}_{t}=\left[\theta\left(\widehat{A S}_{t}^{S U S}+\hat{L}_{t}^{S U S}\right)+(1-\theta)\left(\widehat{A S}_{t}^{C F}+\hat{L}_{t}^{C F}\right)\right]
$$

Equation (10) can be expressed by proxying the rate of variation by logarithmic differences:

$$
\widehat{\operatorname{daet}}_{t}=\left[\theta\left(\widehat{\operatorname{das}}_{t}^{\text {SUS }}+\widehat{d l}_{t}^{S U S}\right)+(1-\theta)\left(\widehat{\operatorname{das}}_{t}^{C F}+\hat{l}_{t}^{C F}\right)\right]
$$

Similarly, according to Equation (5), the growth of technological capital can be expressed as:

$$
\widehat{d k t}_{t}=\left[\psi \widehat{d k t}_{t}^{S U S}+(1-\psi) \widehat{d k t}_{t}^{C F}\right] \text {, }
$$

\footnotetext{
${ }^{8}$ Griliches (1970) and Lucas (1988) also use the expanded Cobb-Douglas production function and incorporate the human capital variable using average years of schooling.
} 
where $d k t_{t}^{S U S}$ is the growth of technological capital associated with the SUS's investments in $\mathrm{R} \& \mathrm{D}, d k t_{t}^{C F}$ is the growth of technological capital of the rest of Spain if the SUS did not exist, $\psi$ is the proportion of technological capital the SUS generates in Spain and $(1-\psi)$ is the proportion of the rest of Spain's technological capital which has not been generated by the SUS.

$K T_{t-1}{ }^{S U S}, K T_{t-1}{ }^{C F}$ and $K T_{t-1}$ are, respectively, the technological capital of the SUS, the technological capital of the rest of Spain, and the total technological capital in the initial year; we find that $\psi=K T_{t-1}{ }^{S U S} / K T_{t-1}$ and $(1-\psi)=K T_{t-1}{ }^{C F} / K T_{t-1}$. According to Equations (11) and (12), the decomposition of growth in Equation (8) can be expressed as:

$\widehat{d y}_{t}=\widehat{d a}_{t}+\alpha \widehat{d k}_{t}+\beta\left[\theta\left(\widehat{d a s}_{t}^{S U S}+\widehat{d l}_{t}^{S U S}\right)+(1-\theta)\left(\widehat{d a s}_{t}^{C F}+\hat{l}_{t}^{C F}\right)\right]+\lambda\left[\psi \widehat{d k t}_{t}^{S U S}+(1-\psi) \widehat{d k t}_{t}^{C F}\right]$.

Equation (13) decomposes the growth of GDP $\left(d y_{t}\right)$ into the contribution of capital $\left(\alpha d k_{t}\right)$, the contribution of the total quantity of labour $\left(\beta\right.$ daet $\left._{t}\right)$, the contribution of technological capital $\left(\lambda d k t_{t}\right)$ and, finally, the contribution of total factor productivity $\left(d a_{t}\right)$.

What is important about Equation (13) is that it associates each of the sources of growth of Spain's GDP with the SUS. Thus, $\left(\beta \theta d_{a s_{t}}^{S U S}\right)$ measures the part of the growth associated with the improvements in quality of the labour factor related to the SUS via the human capital generated, $\left(\beta \theta d l_{t}^{S U S}\right)$ measures the part of growth associated with the increase in the number of occupied persons associated with the SUS via increases in the activity rate and occupation rate and, finally, $\left(\lambda \psi d k t_{t}^{S U S}\right)$ measures the part of growth associated with the increase in technological capital generated by the SUS.

\section{Results for the Spanish university system}

This section contains four subsections that present the results of the estimations of the long-term impacts of the SUS on the national economy. Subsections 4.1 to 4.3 are basic steps to the growth accounting approach, which is at the centre of this paper. In our research, we adopt a counterfactual analysis of how Spanish higher education graduates would have worked without the SUS and we suppose that they would not have attended university. Obviously, a more realistic counterfactual that takes account of dynamic adjustments would necessarily be full of fanciful assumptions and impossible to justify. The 'causality' of our counterfactual scenario is based on statistical association and is difficult to express in terms of actions of agents.

For instance, the different assumptions of our study are relevant especially with respect to the activity rate and the unemployment rate for several reasons, not only on the question of whether a person is active in the labour market, but also for how many hours. Similarly, a change in labour supply may also affect wages, and firms have more unfilled vacancies for higher educated workers that also have effects on wages, and so on. Thus, one must of course be cautious with a counterfactual exercise since it implicitly assumes that agents (higher education graduates) behave in the same way under a different university system setup. The procedure implemented in this paper estimates the contributions of the SUS to the activity rate, the employment rate, the average annual earnings, and to economic growth. However, the procedure does not in any way imply double counting because the increase in earnings and employment are implemented in the growth accounting approach, thus avoiding this problem.

\subsection{Human capital}

The first two rows on the left of the Table 2 present the real and counterfactual average years of education for the Spanish working age population. The real average years of education of the 


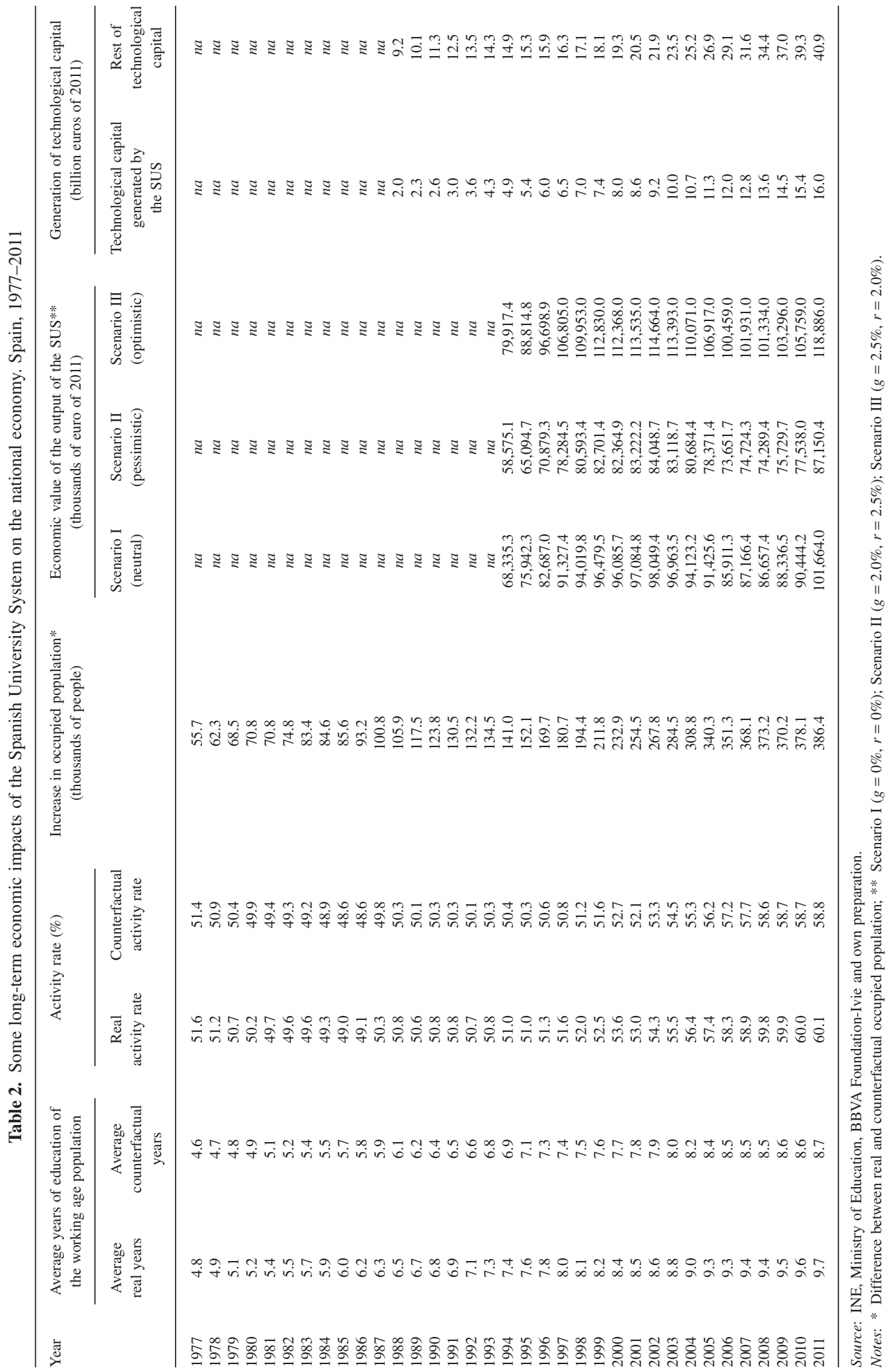


Table 3. Average annual earnings per worker by age groups and educational level (euros of 2011)

\begin{tabular}{lcccc}
\hline & All levels & $\begin{array}{c}\text { Post-compulsory } \\
\text { secondary }\end{array}$ & $\begin{array}{c}\text { University, } \\
\text { short cycle }\end{array}$ & $\begin{array}{c}\text { University, } \\
\text { long cycle }\end{array}$ \\
\hline All ages & 21,968 & 23,142 & 28,092 & 36,062 \\
Under 20 years & 11,330 & $10,338^{\mathrm{c}}$ & $\ldots$ & $\ldots$ \\
20 to 29 years & 16,452 & 15,182 & 19,478 & 21,965 \\
30 to 39 years & 21,895 & 21,183 & 26,359 & 33,398 \\
40 to 49 years & 24,722 & 27,855 & 33,226 & 45,300 \\
50 to 59 years & 27,256 & 32,867 & 40,739 & 51,069 \\
60 years and over & 24,927 & 27,773 & 40,000 & 55,376 \\
\hline
\end{tabular}

Source: INE.

Notes: ${ }^{a}$ University Diploma holders and Technical Engineers. ${ }^{\mathrm{b}}$ Graduates, Higher Engineers and Doctors. ${ }^{\mathrm{c}}$ indicates that the number of sample observations is between 100 and 500, so is unreliable and must be interpreted with caution. Also '. ..' indicates that the INE does not provide the corresponding datum because the number of observations is below 100 .

population aged between 16 and 65 were 9.73 and without the contribution of the SUS they would have been 8.66 years. This means that the human capital generated directly by the Spanish universities was 1.07 years of education per person of working age. In other words, in 2011, 11 per cent of the average endowment of human capital of the population was generated directly by the SUS.

To calculate the value of human capital (see Equations 2 and 3), we consider for each age group the increase in labour earnings when an individual passes from post-compulsory secondary education to university level. Table 3 presents the average annual earnings per worker by age groups for 2011 and only the three educational levels in Spain that include the calculations needed to measure the impact of university activity. An analysis of each age group shows that the average annual earnings per worker is higher, the higher the individual's level of education, reflecting the positive effect of accumulated years of study on salaries. Similarly, for each level of studies, we observe that the average annual earnings per worker increases with the individual's age, and this figure only begins to fall after the age of 60, except in the case of workers with long-cycle university studies. In sum, Table 3 shows that the average annual earnings per worker increase with the years of formal education and also with the years of experience in the labour market.

The value of human capital generated by the SUS is calculated with the data from Table 3 referring to the increase in earnings that university graduates (short cycle and long cycle) obtain on moving from the previous educational level (post-compulsory secondary) to one of the two university education levels. For example, a worker between the ages of 20 and 29 will have an increase in annual earnings of 6,783 euro on if s/he goes from post-compulsory secondary to long-cycle university studies (from 15,182 euro to 21,965 euro each year). This difference in income rises with years of experience in the labour market. Hence, for example, having a (long cycle) university education, results in an increase in annual earnings of 27,603 euro among workers of over 60 years of age. However, to calculate the present value of the increase in earnings, we need to establish assumptions about the growth of wages in the future $(g)$, and also about the discount rate $(r)$ which represents the real interest rate that will prevail in the future. Given the uncertainty about the future evolution of these variables three alternative scenarios are proposed: one optimistic (scenario III), where real wages grow at 2.5 per cent and the real interest rate is 2.0 per cent ( $g=2.5 \%$ and $r=2.0 \%$ ), one pessimistic (scenario II), where real wages grow at 2.0 per cent and the real interest rate is 2.5 per cent $(g=2.0 \%$ and $r=2.5 \%)$ and, finally, a neutral one (scenario I), where real wages do not grow and the real interest rate is 0 per cent $(g=0 \%$ and $r=0 \%)$. The choice of the above values in the different scenarios is not 
Table 4. Wealth human capital per individual and value of university output (thousands of euros of 2011)

\begin{tabular}{lccr}
\hline & $\begin{array}{c}\text { Secondary post } \\
\text { compulsory }^{\mathrm{a}}\end{array}$ & $\begin{array}{c}\text { Tertiary } \\
\text { short cycle }^{\mathrm{b}}\end{array}$ & $\begin{array}{c}\text { Tertiary } \\
\text { long cycle }^{\mathrm{c}}\end{array}$ \\
\hline Scenario I $(g=0 \%, r=0 \%)$ & 981.7 & $1,269.4$ & $1,611.7$ \\
Scenario II $(g=2.0 \%, r=2.5 \%)$ & 854.9 & $1,100.3$ & $1,391.5$ \\
Scenario III $(g=2.5 \%, r=2.0 \%)$ & $1,131.5$ & $1,469.7$ & $1,872.8$ \\
\hline
\end{tabular}

Source: INE and own preparation.

Notes: a Secondary Education II and Vocational Training, middle and higher grade. ${ }^{\mathrm{b}}$ University diplomas and engineering technicians. ${ }^{c}$ Graduates, higher engineers and doctors. The parameter $g$ is the rate of growth of real salaries and $r$ is the real interest rate.

arbitrary and was established by observing wage growth and evolution of the real interest rate on Spain's economy since the middle of the twentieth century. Table 4 presents the human capital wealth for the post-compulsory secondary and university levels of education in these three alternative scenarios.

As can be observed, adopting the different assumptions notably influences the level of human capital wealth of each educational level, though not their relative positions. Table 4 shows that in the neutral scenario (scenario I), the present value of salary income (human capital wealth) of an individual with post-compulsory secondary education is nearly one million euro (981,704 euro), that of a short-cycle university graduate nearly 1.3 million euro and that of a long-cycle university graduate over 1.6 million euro. Thus, going from post-compulsory secondary education to a long-cycle university education implies an increase of 630,000 euro (536,600 euro in the pessimistic scenario and 741,300 euro in the optimistic scenario).

The last calculation to obtain the value of the human capital generated by the SUS consists of combining the previous results with the number of university graduates in each academic year. Table 2 presents the results for each of the assumptions considered. According to the neutral scenario (scenario I), the output generated by the whole SUS in 2011 was 101,664 million euro. The value of the output varies between 87,150 million euro in the most pessimistic scenario (scenario II) and 118,886 million euro in the optimistic scenario (scenario III).

\subsection{Activity rate and employment}

We use the estimations from model (1) of Table 1 to calculate the series of the counterfactual active population for Spain in which the effect on the activity rate of having completed university studies is eliminated. In other words, a counterfactual activity rate is calculated that, according to the estimations from model (1), would correspond to a situation in which the SUS had not produced any university graduates and, consequently, individuals would be less likely to participate in the labour market. The SUS's contribution to the increase in the activity rate in the Spanish economy is therefore computed as the difference between the two rates (real and counterfactual). Table 2 shows the evolution of the activity rate and the counterfactual rate. In 2011 the activity rate was 60.1 per cent. However, if Spanish university graduates had not studied in the SUS and had the same behaviour with regard to their participation in the labour market as individuals with post-compulsory secondary education, the activity rate in Spain would have been 58.8 per cent. Therefore, the SUS has an impact of 1.33 percentage points on the Spanish economy's activity rate.

Again, the procedure to calculate the contribution of SUS to occupation in the Spanish economy is by using the estimations of model (2) of Table 1 to compute the counterfactual series of Spain's occupied population, in which the positive effect on the real probability of 
employment of having completed university is eliminated. Thus, the difference between the real occupied population series and the counterfactual occupied population series constitutes the increase in the occupied population due the contribution of the SUS.

These calculations indicate that the unemployment rate in 2011 is 21.5 per cent and without the contribution of the SUS it would have been 22.2 per cent ( 0.7 percentage points higher). However, Table 2 presents the contribution of the SUS to the increase in the occupied population in absolute terms. The column showing the increase in occupied population in Table 2 reveals a very positive and growing contribution of SUS which only sees a fall in its rate of growth with the start of the economic crisis. In 2011 Spain's occupied population totalled 18,156,000. Without the SUS's contribution the occupied population in 2011 would have been 17,770,000, a difference of 386,400 occupied persons, representing 2.1 per cent of total employment in Spain.

\subsection{Technological capital}

The technological capital stock of the Spanish economy is estimated by Equation (5), and through R\&D expenditure by applying a rate of depreciation of 15 per cent. ${ }^{9}$ With the methodology described in subsection 3.3 and the R\&D expenditure series we estimated the stock of technological capital generated both by the Spanish universities and by all other sectors since the year 1988. The results are presented in the two rightmost columns of Table 2. The stock of technological capital generated in 2011 was 56.9 billion euro, while that generated by the Spanish University System was 16.0 billion euro. That is, the SUS generated 28.1 per cent of Spain's technological capital. ${ }^{10}$

\subsection{Economic growth}

The SUS has had a very positive impact on the effectively utilized human capital, due to its contribution to the increase in the activity rate and in employment in Spain (386,400 workers). We therefore use the term quantity effect to refer to the SUS's contribution to Spain's economic growth associated with the impact of the SUS on the employed population. It has also been estimated that 11 per cent of the human capital of the Spanish economy can be attributed directly to the SUS. Similarly, we use the term quality effect to refer to the SUS's contribution to Spain's economic growth associated with the impact of the SUS on human capital.

Another of the sources of economic growth is technological capital. In the previous subsection we estimated the technological capital generated by the SUS through its R\&D activities (16.0 billion euro, 28.1 per cent of Spain's technological capital). We therefore use the term technological capital effect to refer to the contribution of the SUS to Spain's economic growth associated with the impact of the SUS on technological capital.

Table 5 summarizes the origin of the statistical information used to calculate the decomposition of the growth of the Spanish economy. The calculations were performed within the framework of the theory of growth accounting (Solow 1957), a technique commonly used to

\footnotetext{
9 There is no unanimity as to the rate to be used. Pakes and Shankerman (1984) and Hall (1988) use a maximum rate of $25 \%$. Other studies apply lower rates similar to those used for physical capital stock. We selected a rate of $15 \%$, as used by Hall and Mairesse (1992) and by Puente and Pérez (2004).

10 Different rates of discount make different contributions to the generation of technological capital, because the higher the discount rate, the lower the technological capital generated. Hence, with a 10 per cent rate of discount, the technological capital generated will reach 20 billion euro, with $20 \%, 12.9$ billion euro, and with $25 \%, 10.8$ billion euro.
} 
Table 5. Sources of data for economic growth in Spain

\begin{tabular}{|c|c|c|}
\hline Variable & Definition & Source \\
\hline Y: Level of income & GDP in real terms & $\begin{array}{l}\text { INE. Contabilidad regional de España } \\
\text { (various years) }\end{array}$ \\
\hline K: Physical capital & $\begin{array}{l}\text { Capital stock (private, non-dwellings) } \\
\text { in real terms. }\end{array}$ & Fundación BBVA-Ivie. \\
\hline AET: Years de education & $\begin{array}{l}\text { Years of education of the occupied } \\
\text { population }\end{array}$ & Fundación Bancaja-Ivie. \\
\hline L: Occupied & Occupied population & Fundación Bancaja-Ivie. \\
\hline KT: Technological capital & See Equations (8)-(13) & $\begin{array}{l}\text { INE. Estadística sobre activities } \\
\text { de R\&D. }\end{array}$ \\
\hline AS: Average years of education & $\begin{array}{l}\text { Average years of education of the } \\
\text { occupied population }\end{array}$ & Fundación Bancaja-Ivie. \\
\hline \multicolumn{3}{|c|}{ Contribution to generation of income ${ }^{a}$} \\
\hline$\beta$ : Labor & $\begin{array}{l}\text { Ratio of remuneration to employees/ } \\
\text { GDP }\end{array}$ & $\begin{array}{l}\text { INE. Contabilidad regional de España } \\
\text { (various years) }\end{array}$ \\
\hline$\lambda$ : Technological capital & $\begin{array}{l}\text { Elasticity of the GDP to technological } \\
\text { capital }(\lambda=0.08)\end{array}$ & López and Sanau (2001) \\
\hline$\alpha$ : Physical Capital & $\begin{array}{l}\text { Calculated as } \alpha=1-\beta-\lambda \text {. } \\
\text { Constant returns to scale assumed. }\end{array}$ & $\begin{array}{l}\text { INE. Contabilidad regional de España } \\
\text { (various years) }\end{array}$ \\
\hline$\theta$ & $\begin{array}{l}\text { Proportion of the total years of } \\
\text { education generated by the SUS }\end{array}$ & $\begin{array}{l}\text { Fundación Bancaja e Ivie. } \\
\text { (various years) }\end{array}$ \\
\hline$\psi$ & $\begin{array}{l}\text { Proportion of the technological capital } \\
\text { generated by the SUS }\end{array}$ & $\begin{array}{l}\text { INE, Statistics on R \& D. } \\
\quad \text { (various years) }\end{array}$ \\
\hline
\end{tabular}

Source: Own preparation.

Notes: ${ }^{a}$ The value of $\beta$ is 0.65 in 1989 and 0.61 in 2010; the value of $\alpha$ is 0.27 in 1989 and 0.31 in 2010; the value of $\theta$ is 0.08 in 1989 and 0.10 in 2010; finally, the value of $\psi$ is 0.19 in 1989 and 0.28 in 2010 .

decompose income growth in contributions for the use of different amounts of each of the factors of production economics, taking into account the value attributed to their contributions. The basic idea is that, under assumptions such as the existence of perfect competition and constant returns to scale, the contribution of each factor to production can be estimated through its own real growth rate multiplied by the share of income of that factor in total income.

In Equation (13), the parameters $\alpha, \beta$ and $\lambda$ are the shares of the income of physical capital, labour (wages) and technological capital, respectively, in the total income (GDP). The parameters $\alpha$ and $\beta$ are calculated from data provided annually by the Spanish Statistical Office (INE 2012 ), dividing each of these rents by GDP each year. In the case of technological capital $(\lambda)$, since the Spanish Statistical Office does not provide information on this variable and we have taken the value 0.08 estimated by López and Sanau (2001). Thus, the value of $\beta$ is 0.65 in 1989 and 0.61 in 2010, and the value of $\alpha$ is 0.27 in 1989 and 0.31 in 2010 (see Table 5 where the physical capital parameter is calculated as $\alpha=1-\beta-\lambda$ ). Additionally, the parameter $\theta$ is the proportion of the total years of education generated by the SUS (0.08 in 1989 and 0.10 in 2010), and $(1-\theta)$ is the proportion of the rest of the years of education in the total; the parameter $\psi$ is the proportion of the technological capital generated by the SUS in Spain (0.19 in 1989 and 0.28 in 2010); and $(1-\psi)$ is the proportion of the rest of Spain's technological capital which has not been generated by the SUS.

Table 6 shows the sources of economic growth of Spain's economy for the period 19892010. The Spanish economy grew at an average annual rate of 2.57 per cent during the period analysed. The main source of economic growth is the labour factor with 2.14 percentage points, of which 1.45 points can be attributed to the increase in the employed population and the 
Table 6. Sources of economic growth in Spain. Contribution of the SUS to economic growth. 1989-2010

\begin{tabular}{|c|c|c|c|c|}
\hline & 1989-2010 & 1989-1994 & 1995-2000 & 2001-2010 \\
\hline GDP & 2.57 & 2.20 & 3.81 & 2.04 \\
\hline Physical capital & 1.42 & 1.32 & 1.53 & 1.42 \\
\hline Labour & 2.14 & 1.29 & 3.69 & 1.72 \\
\hline Spanish university system & 0.44 & 0.30 & 0.63 & 0.40 \\
\hline Quantity & 0.42 & 0.28 & 0.60 & 0.39 \\
\hline Quality & 0.02 & 0.02 & 0.02 & 0.01 \\
\hline Counterfactual & 1.70 & 0.99 & 3.06 & 1.32 \\
\hline Quantity & 1.03 & -0.05 & 2.27 & 0.94 \\
\hline Quality & 0.67 & 1.04 & 0.79 & 0.38 \\
\hline Technological capital & 0.56 & 0.78 & 0.42 & 0.52 \\
\hline Spanish university system & 0.18 & 0.24 & 0.17 & 0.14 \\
\hline Counterfactual & 0.39 & 0.53 & 0.25 & 0.38 \\
\hline TFP & -1.56 & -1.18 & -1.84 & -1.62 \\
\hline
\end{tabular}

Source: INE, Bancaja Foundation-Ivie, and own preparation.

remaining 0.69 points to the increase in quality. Table 6 also shows that, of the 1.45 per cent growth associated with the number of employed, 0.42 percentage points are due to the indirect contribution of the SUS. Additionally, of the 0.67 per cent growth associated with improvements in quality, 0.02 percentage points are due to the increase in human capital generated by the SUS. Therefore, via improvements in the quantity and quality of labour, the contribution of the SUS to Spain's growth totalled 0.44 percentage points.

The second source of Spain's economic growth is the increase in physical capital, with a contribution of 1.42 percentage points. Similarly, technological capital contributed to the growth of the Spanish economy by 0.56 percentage points. The result of the decomposition indicates that 0.18 percentage points can be attributed to the impact of the technological capital generated by the SUS.

Finally it should be noted that the total factor productivity (TFP) makes a negative contribution to Spanish economic growth of -1.56 percentage points in the whole period analysed and especially in the final part (2001-2010). However this result is not remarkable and, in the case of Spain, various studies have found very similar results. OECD publications (Mas and Quesada $2005,2009)$ report a fall in productivity of -2.08 per cent and -2.05 per cent per year, respectively, for the period 1995-2000 in Spain (compared to -1.94\% obtained in this study). These authors attribute this negative contribution of TFP in Spain to the notable increases in the stock of productive resources (human capital and especially capital deepening) and to the poor use of these accumulated resources. ${ }^{11}$

Considering all the impacts of the SUS simultaneously (quantity, quality and technological capital effects) we observe that, for the total of the period analysed, the Spanish universities contributed to Spain's growth by 0.62 percentage points $(0.44$ via increases in quantity and quality of labour and 0.18 via increases in technological capital). These 0.62 percentage points corresponding to the SUS's contribution, represent 15.04 per cent of the total contribution of all inputs in the period 1989-2010. ${ }^{12}$

11 Similarly, Díaz and Franjo (2014) state that the poor evolution of TFP in the Spanish case is because investment specific technical change is very low and investment in structures in Spain is inefficiently high.

${ }^{12}$ In the period 1989-2010 the growth of all inputs represented a total contribution of $4.12 \%(1.42 \%$ of the contribution of physical capital, $2.14 \%$ of the contribution of labour and $0.56 \%$ of the contribution of technological capital). 


\section{Conclusions}

This paper makes an original methodological and empirical contribution to the already abundant literature on the socio-economic impact of universities, developing a metric that allows estimation of its long-term economic effects. The proposal is based on the calculation of the human and technological capital generated by the universities and the value that the productive system yields on these factors. Its contribution is estimated by comparing the current situation - in which the contributions of the universities are taken into account - and a hypothetical (counterfactual) one in which human and technological capital generated by universities is not present in productive activities.

The methodology presented is of interest since it allows the contributions that universities make to the increase in productive factor endowments and productivity to be calculated with explicit and rigorous criteria. The empirical application of the method confirms the importance of university contributions on the supply side and in the long run. A numerical summary of these contributions indicates that 0.62 percentage points of the SUS's contribution represent 15.04 per cent of the total contribution of all inputs in the period 1989-2010 in the Spanish economy. Of this amount, 0.44 percentage points were via increases in quantity and quality of labour, and 0.18 points via increases in technological capital.

The study contains two important lessons for the design of growth policies in general and university policies in particular. First, the results confirm that the pursuit of a knowledge-based growth strategy sustained by universities is appropriate and supported by the fact that the human and technological capital generated by these institutions represents an important part of the additional value added generated. Second, the methodology shows that the criterion for measuring the contributions of universities must consider the market value of the resources generated by them. Following this reasoning, university policies should be evaluated by their direct results - teaching and research - and indirect - employability and wages of graduates and technological transfer to firms. The greater the human and technological capital generated and its higher productive use, the larger the socio-economic impact of the universities.

\section{References}

Acemoglu D, Autor DH (2011) Skills, tasks, and technologies: Implications for employment and earnings. In: Ashenfelter O, Card D (eds) Handbook of labor economics, vol. 4b. Elsevier, New York

Autor DH, Levy F, Murnane RJ (2003) The skill content of recent technological change: An empirical exploration. The Quarterly Journal of Economics 118: 1279-1333

Autor DH, Price BM (2013) The changing task composition of the US labor market: An update of Autor, Levy and Murnane (2003). MIT Monograph, Cambridge, MA

Anselin L, Varga A, Acs Z (1997) Local geographic spillovers between university research and higher technology innovations. Journal of Urban Economics 42: 422-448

Arbo P, Benneworth P (2007) Understanding the regional contribution of higher education institutions: A literature review. Education Working Paper 9. OECD, Paris

Basant R, Mukhopadhyay P (2009) An arrested virtuous circle? Higher education and high-tech industry in India. Working Paper 2009-05-01, Indian Institute of Management, Ahmedabad

Bleaney MF, Binks MR, Greenaway D, Reed G, Whynes DK (1992) What does a university add to its local economy? Appied Econonomics 24: 305-311

Bramwell A, Wolfe DA (2008) Universities and regional economic development: The entrepreneurial University of Waterloo. Research Policy 37: 1175-1187

Caffrey J, Isaacs H (1971) Estimating the impact of a college or university on the local economy. American Council on Education, Washington DC

Canterbury City Council (2001) The economic impact of four large educations institutions on the Canterbury district economy. Canterbury City Council, Canterbury

Carroll MC, Smith BW (2006) Estimating the economic impact of universities: The case of Bowling Green State University. The Industrial Geographer 3: 1-12 
Díaz A, Franjo L (2014) Capital goods, measured TFP and growth: The case of Spain. Center for Fiscal Policy Working Paper 01-2014. École polytechnique fédérale de Lausanne

Drucker J, Goldstein H (2007) Assessing the regional economic development impacts of universities: A review of current approaches. International Regional Science Review 30: 20-46

Elhorst JP, Zeilstra AS (2007) Labour force participation rates at the regional and national levels of the European Union: An integrated analysis. Papers in Regional Science 86: 525-549

Fearon J (1996) Causes and counterfactuals in social science: Exploring an analogy between cellular automata and historical processes. In: Tetlock PE, Belkin A (eds) Counterfactual thought experiments in global politics: Logical, methodological, and psychological perspectives. Princeton University Press, Princeton, NJ

Feldman M, Desrochers P (2003) Research universities and local economic development: Lessons from the history of the Johns Hopkins University. Industry and Innovation 10: 5-24

Frascati M (2002) Proposed standard practice for surveys on research and experimental development. OECD, Paris

Garrido-Yserte R, Gallo-Rivera MT (2010) The impact of the university upon local economy: Three methods to estimate demand-side effects. The Annals of Regional Science 44: 39-67

Glaeser E, Saiz A (2003) The rise of skilled city. Working Paper 10191. NBER, Cambridge, MA

Giesecke JA, Madden JR (2005) A CGE assessment of a university's effects on a regional economy: Supply-side versus demand-side effects. European Regional Science Association Conference Papers (45th Congress of the ERSA)

Goddard J, Kempton L (2011) Connecting universities to regional growth: A practical guide. European Commission, Brussels

Goldstein H, Renault C (2004) Contributions of universities to regional economic development: A quasi-experimental approach. Regional Studies 38: 733-746

Griliches Z (1970) Notes on the role of education in production functions and growth accounting. In: Hansen WL (ed) Education, income, and human capital. NBER Books, Cambridge, MA

Hall B (1988) L'effect des dépenses en R\&D sur la productivité du travaillau Quebec. Actualité Economique 64: 396-415

Hall B, Mairesse J (1992) Exploring the relationship between R\&D and productivity in French manufacturing firms. Working Paper 3956. NBER, Cambridge, MA

Heckman JJ (1979) Sample selection bias as a specification error. Econometrica 47: 153-161

INE (2012) Instituto Nacional de Estadística. URL: http://www.ine.es/inebmenu/mnu_cuentas.htm

Jorgenson D, Fraumeni B (1992) The output of the education sector. In: Griliches Z (ed) Output measurement in the services sector. University of Chicago Press, Chicago, IL

Kelly U, McLellan D, McNicoll I (2009) The impact of universities on the UK economy. Universities UK, London

Lane JE, Johnstone DB (eds) (2012) Universities and colleges as economic drivers. Measuring higher education's role in economic development. SUNY Press, New York

Lendel I (2010) The impact of research universities on regional economies: The concept of university products. Economic Development Quarterly 24: 210-230

Leslie L, Lewis D (2001) Economic magnet and multiplier effects of the University of Minnesota. Sesquicentennial Symposium, August 23, 2001. University of Arizona and University of Minnesota

Leslie LL, Slaughter SA (1992) Higher education and regional development. In: Becker WE, Lewis DR (eds) The economics of American higher education. Kluwer Academic Publishers, Dordrecht

López C, Sanau J (2001) Impacto del capital tecnológico en la producción industrial. Economía Industrial 341: $103-112$

Lucas R (1988) On the mechanics of economic development. Journal of Monetary Economics 22: 3-42

Mas M, Quesada J (2005) ICT and economic growth: A quantification of productivity growth in Spain 1985-2002. Statistics Working Paper 2005/4. OECD, Paris

Mas M, Quesada J (2009) The Role of ICT on the Spanish productivity slowdown. In: OECD and FSO (eds) Productivity measurement and analysis. OECD, Paris

McMahon W (2009) Higher learning, greater good. The private and social benefits of higher education. The Johns Hopkins University Press, Baltimore, MD

Moretti E (2004) Estimating the social return to higher education: Evidence from longitudinal and repeated crosssectional data. Journal of Econometrics 121: 175-212

OECD (2007) Higher education and regions: Globally competitive, locally engaged. OECD, Paris

OECD (2009) Education at a glance 2009. OECD indicators. OECD, Paris

Pakes A, Schankerman M (1984) The rate of obsolescence of patents, research gestation lags and the private rate of return to research resources. In: Griliches $\mathrm{Z}$ (ed) $R \& D$, patents and productivity. University of Chicago Press, Chicago, IL

Pastor JM, Pérez F (2008) La contribución socio-económica de la Universidad del País Vasco. Servicio Editorial de la Universidad del País Vasco, Bilbao

Pastor JM, Pérez F (2009) La contribución socio-económica de las universidades públicas valencianas. Publicacions de la Universitat de València, Valencia 
Pastor JM, Peraita C (2012) La contribución socio-económica del sistema universitario español. Ministerio de Educación, Secretaría General de Universidades, Madrid

Pastor JM, Pérez F, Fernández de Guevara J (2013) Measuring the local economic impact of universities: An approach that considers uncertainty. Higher Education 65: 539-564

Porter M (2007) Colleges and universities and regional economic development: A strategic perspective. Forum for the Future of Higher Education, Cambridge, MA

Power D, Malmberg A (2008) The contribution of universities to innovation and economic development: In what sense a regional problem? Cambridge Journal of Regions, Economy and Society 1: 233-245

Puente S, Pérez M (2004) Las series de stock de capital humano y tecnológico en los indicadores de convergencia real. Boletín Económicodel Banco de España 12: 63-72

Ryan GJ, Malgieri P (1992) Economic impact studies in community colleges: The short cut method. Resource Paper 48. National Council for Resource Development, Washington, DC

Serrano L, Pastor JM (2002) El valor económico del capital humano en España. Fundación Bancaja, Valencia

Siegfried JJ, Sanderson AR, McHenry P (2007) The economic impact of colleges and universities. Economics of Education Review 26: 546-558

Simha OR (2005) The economic impact of eight research universities on the Boston region. Tertiary Education and Management 11: 269-278

Solow R (1957) Technical change and the aggregate productive function. Review of Economics and Statistics 39: $312-320$

Sudmant W (2009) The economic impact of the University of British Columbia. Planning and Institutional Research, UBC, Vancouver

Varga A (ed) (2009) Universities, knowledge transfer and regional development: Geography, entrepreneurship and policy. Edward Elgar, Cheltenham 
Resumen. A diferencia de los estudios previos sobre el impacto económico de las universidades y que se centran en la demanda, este estudio se centra en los efectos de las universidades en el lado económico de la oferta. Este artículo emplea un estudio de caso del sistema universitario español para proponer una metodología basada en escenarios contrafactuales y la medida del crecimiento para estimar los impactos a largo plazo de las universidades en sus economías regionales. El estudio evalúa los impactos estilizados de las actividades de las universidades en el capital humano, los salarios y la ocupación de la población en edad laboral en la generación de capital tecnológico y, por ende, en el crecimiento del PIB de la economía española en el periodo 1989-2010.

要約: 需要サイドに焦点を当てた、大学の経済的影響に関する従来の研究とは対照的に、本研究で は経済の供給サイドに焦点を当てる。スペインの大学システムの事例研究を通じて、本論文は、反 実仮想的シナリオと大学が地域経済に与える長期的影響を推計する成長会計に基づいた方法論を提 示する。我々の研究は、大学の活動が与えた、人的資本、生産年齢人口の報酬と職業、技術的資本 の創出、そして1989年から2010年の間のスペイン経済のGDP成長率に対する定型化された影響を評 価する。 